University of Rhode Island

DigitalCommons@URI

Open Access Master's Theses

1979

\title{
THE "CATHOLIC ETHIC" AND THE "SPIRIT OF FINANCIAL CAPITALISM"
}

Mary Lou DeCiantis Hurlbut

University of Rhode Island

Follow this and additional works at: https://digitalcommons.uri.edu/theses

\section{Recommended Citation}

Hurlbut, Mary Lou DeCiantis, "THE "CATHOLIC ETHIC" AND THE "SPIRIT OF FINANCIAL CAPITALISM"'" (1979). Open Access Master's Theses. Paper 1780.

https://digitalcommons.uri.edu/theses/1780

This Thesis is brought to you for free and open access by DigitalCommons@URI. It has been accepted for inclusion in Open Access Master's Theses by an authorized administrator of DigitalCommons@URI. For more information, please contact digitalcommons-group@uri.edu. 


\section{THE "CATHOLIC ETHIC" AND THE \\ "SPIRIT OF FINANCIAL \\ CAPITALISM"}

BY

MARY LOU DECIANTIS HURLBUT

A THESIS SUBMITTED IN PARTIAL FULFILLMENT OF THE REQUIREMENTS FOR THE DEGREE OF

MASTER OF ARTS

IN

SOCIOLOGY

UNIVERSITY OF RHODE ISLAND

1979 


\section{ABSTRACT}

This study proposes to treat the Catholic Church as an organization with internal and external aspects comparable to strictly secular organizations with the central hypothesis being that as the structural characteristics of the church resemble those of other large scale multinational organizations, the behavior pattern will also. This phenomenon would represent a significant case of shifting goals in an organization. The Church is an organization dedicated to a non-mundane ideology, yet some of its offices are strictly concerned with high level finance. Newspaper and journalistic accounts of the wealth amassed by Vatican financiers are a source of controversy both within and without the Church. The Vatican has reportedly made sizable worldwide investments in the areas of real estate, banking, private and government industries. At the same time, it continues to function as a major philanthropic religious institution.

A study of the literature written about the modern Church has revealed that this disparity exists within its structure as well as its operations. Questions have been raised regarding the extent to which the church is operating as a selfinterested corporation and the degree of acceptance that will be afforded such a policy by its members. 
In this paper I examine these issues and suggest that the Church is a viable global corporate entity and that some aspects of its organization may serve as a model to be emulated by other global concerns. 
ACKNOWLEDGMENTS

I would first like to note that Dr. Alan Wells' seminar on Multinational Corporations inspired me to undertake this research project. I am also indebted to Dr. Wells for enriching my life with a fuller understanding of the word "paragraph."

Sincere thanks are extended to Dr. Robert Gardner and Dr. Roger Sennott for taking the time to sit on my committee, and for the informative and enjoyable courses they offered during my enrollment at U.R.I. I also extend a note of appreciation to Dr. Frank Costigliola, who also agreed to review my thesis.

To my good friend, Dr. Richard Travisano, I owe a special debt of gratitude for many hours of good conversation in and out of the classroom. His confidence in my abilities, and his support and encouragement were greatly instrumental in focusing my direction to the field of Sociology as a career.

Words cannot express my heartfelt thanks to my parents and to my favorite aunt, Lena, for their countless hours of babysitting and dinner invitations, without which this thesis would not have been written.

For the precious few moments of peace and quiet they allowed me, I thank my daughters, Jennifer and Vanessa.

Finally, to Bill, for his almost constant tolerance of me during the research and writing of this study, I dedicate my thesis. 
TABLE OF CONTENTS

ABSTRACT. . . . . . . . . . . . . . . . . . $i$

ACKNOWLEDGMENTS . . . . . . . . . . . . . . ii

I. THE STRUCTURE OF THE CATHOLIC CHURCH. . . . . . 4

Bureaucratic Characteristics of the

Catholic Church and Multinational

Corporations . . . . . . . . . . . . . 1

Structural Characteristics of the

Catholic Church and Multinational

Corporations . . . . . . . . . . . . . 7

Organizational structure. . . . . . . . . . . 11

Financial Base of the Catholic Church . . . . 16

The Church/State Relationship in Italy. . . . 23

The Vatican in Politics... . . . . . . . . 28

II. GLOBAL FINANCIAL DEALINGS OF THE CATHOLIC

$\mathrm{CHURCH}$. . . . . . . . . . . . . . 31

Corporate Planning. . . . . . . . . . . 31

Global Banking . . . . . . . . . . . . 34

Multinational Corporations and State
Governments..... . . . . . 36

III. RELIGIOUS IDEOLOGY VS. FINANCE. . . . . . . . 46

Catholic Church's Foreign Aid Policy and

Diplomatic Relations .......... 46

Vatican Missionary Activity . . . . . . . . 54

IV. CATHOLIC CHURCH AS A MULTINATIONAL CORPORATION. 59

Catholic Church's Multinational Operations. . 59

Multinational Corporation Characteristics . . 60

Conclusion . . . . . . . . . . . . . 64

SELECTED BIBLIOGRAPHY . . . . . . . . . . 66 


\section{LIST OF TABLES}

1. The Structure of the Catholic Church. . . . . . . 13

2. Vatican Portfolio (Italian Holdings/Vatican

Representatives). . . . . . . . . . . 20 


\section{INTRODUCTION}

The Roman Catholic Church has fashioned an image of itself as the church of the poor and downtrodden. The early church preached a policy of charity and fraternity, easily carried out when members were few and socially homogenous. The goals of the church, then, were overtly spiritual. Nonetheless, the Church became a complex organization of vast scope and took on many secular features dictated by this hierarchical structure. For large numbers of churchmen, other goals came to the fore. The organization of the Church crossed national boundaries and established it as a prototypic multi-national corporation necessitating foreign, financial and political policy development.

The historical emergence of the Church as a global corporation is beyond the scope of this paper and the focus is on the modern church. The topic of concern within the Church is the rigor with which it is pursuing wealth and power and with which it sagaciously vies for a favorable position in the world economy. These actions seem to have resulted in a loss of credibility by the church hierarchy vis à vis the church faithful. This shifting in goals has been of great significance to both Church members and nonmembers.

Despite protests to the contrary by the church, there is mounting evidence being compiled by newspapers, journals, 
periodicals, etc. that the Vatican is dispensing far more than salvation for the soul. The internal behavior and affairs among the Pontifical key personnel as well as the Pontiff's relationships with government bureaucracies parallel the workings of other global corporations, marked by such characteristics as complex communications networks, secrecy, and "statelessness" (Barnet \& Muller, 1974, Galtung 1971). Their policies promote finance over ideology. (Scheer 1974, Turner 1970) The church says it needs money, but often does not use it for the growth of the "church" but for growth's sake. A multi-national seeks a foothold in any country with a market for the goods it sells and negotiates for rights and privileges vis-a-vis each country's populace and this study proposes to examine this dimension of the actions of the Catholic Church. A discussion of this issue has particular significance to the area of organizational theory concerning the extent to which a hostile or friendly environment affects the workings of an organization (Boulding 1968, Etzioni 1965).

One of the basic tenets of organizational theory is that self-perpetuation is one of the most powerful forces of an organization and a variety of tactics are employed to ensure this goal (Blau, 1971). Since the Catholic Church has a long history as a multi-national organization and is perhaps more well known than other more recent arrivals on the global scene, the author feels an examination of the policies it employs to adapt itself to its environment will 
reveal that they are markedIy similar to tactics now being employed by secular global corporations. A comparative analysis of the Catholic Church and other multinational concerns should yield a new outlook on the role of the Catholic Church in the world. 


\section{THE STRUCTURE OF THE CATHOLIC CHURCH}

Bureaucratic Characteristics of the Catholic Church and Multinational Corporations

All viable organizations, whether categorized as secular or religious, economic or non-economic, are basically concerned with the advancement of their members and the growth itself of their enterprises. (Boulding:1968:4) The global marketplace is traversed by salesmen and/or "missionaries" (Boulding:1968:27) promoting a new product or offering an old one in new trappings. The corollary between the blind devotion of the missionary and the company loyalty of the business executive is fascinating: both are "organization men". Such adherence to an organization's policies often stems from the attraction of the ongoing growth pattern of the organization itself. Identification with dynamic enterprises affords an individual a strong sense of status.

The sharply delineated social structure of a global organization with its formalized role systems affords its members a clear status and authority. In the following excerpt from Merton's Bureaucratic Structure and Personality an analogy can be drawn to the structure of the Catholic Church:

Authority....inheres in the office and not in the particular person who performs the official role. official action ordinarily occurs within the framework of pre-existing rules of the organization. The system of prescribed relations between the various offices involves a considerable degree of formality 
and clearly defined social distance between the occupants of these positions. Formality is manifested by means of a more or less complicated social ritual... (Etzioni:1965:48)

The rise to the top within the Catholic church is along a clearly prescribed route: pastor, monseigneur, bishop, archbishop, cardinal, and possibly pope. Each station is endowed with certain rights, privileges and duties as in a secular organization, the "company man's" rise to the top is also carefully delineated. The emphasis in the bureaucratic structure of the Catholic Church and other organizations then is on discipline and set behavioral norms.

A defensive posture is often adopted and an "esprit de corps" will exist among the bureaucratic higher ups. Those outside the inner circle are disallowed access and information. Such a condition has festered for years within the Catholic Church. Accusations of conservatism and traditionalism are frequently hurled at the church as its bureaucratic structure is not viewed as accessible or adaptable. Spiritual and fiscal policies are implemented without regard to popular sentiment.

Directors of big business are also accused of forming self-perpetuating oligarchies (Boulding:1968:63). The same is certainly true of the Catholic Church's directorate, the Roman Curia. Their single-minded devotion to the maintenance of the status quo within the Church's organization is indicative of their basic desire to survive handily using the means at their disposal, i.e. excommuication, which is synonymous with the business executive's blacklist. (Boulding:1968:55) 
The Catholic Church is big business. As in all big business enterprises there is a concentration of power at the top of the bureaucratic hierarchy. When the business is global in scope, this power is largely unchecked by national governments or labor unions. Free competition was formerly viewed as being an effective brake on a potentially unbridled capitalistic system, but modern business corporations have grown to the point where they monopolize the market unopposed. Literature on multinational corporations (Wells, 1977 and Levinson, 1971) suggest that this concentrated power is overshadowing that of national governments, threatening and sometimes crippling their economic policies. The inability of the U.S. government to arrest the current runaway inflation rate and its ineffectiveness in re-establishing the value of the dollar are indications of the weakening powers of nation states in general.

Labor unions, still nationalistic in their outlook, can not effectively deal with an international corporation and are to an extent at the mercy of the whims of corporate directors. Dissent within subsidiaries is frowned upon and contained within isolated incidents. For the first time in its history there was a strike within the ranks of the church in 1978 and it was short lived. In a diocese in ItaIy, fifty country priests started a work slowdown protesting a Vatican order transferring their four parish churches from the Trevinto diocese to the Sulmora diocese. The Vatican at the time was engaged in a policy of reorganizing and reducing 
the number of dioceses. The priests in this area argued that they had guarantees protecting them from such transfers. A three-member delegation met with Cardinal Baggio, Prefect of the Congregation of Bishops, who was unbending to their demands. This would have set a precedent of acceeding to local subsidiaries the Vatican did not want, nor would any other global corporation.

\section{Structural Characteristics of the Catholic Church} and Multinational Corporations

The supra state of the Catholic Church is unique in that the Pope is not only the spiritual leader of the world's 500 million Catholics, but is the secular ruler of the Vatican City state which actively promotes and defends the worldly and other worldly policies of the Pontiff. Until the election of John Paul II, Popes have traditionally been of Italian descent supported by the almost exclusively Italian members of their board of directors, the Curia. This homogeneity within the upper echelon aided in effectively controlling the administration of religious and fiscal policies.

The Catholic Church has, in effect, its own "home nation" from whence it dictates policies to be carried out on a world-wide basis. Papal instructions filter down the hierarchy to the various Bishop's offices and from there they are echoed from the local parish pulpit. Scheer (1974:87) described secular multinational companies in essentially the same terms: 
...multinationals are big companies which engage in production using local labor in more than one country and are in fact national corporations in the explicit sense that the parent organization owns or controls the affiliates and is situated in a 'home' nation. Most of the top management and board of directors come from that nation and it is that nation's government and army which provide the multinationals with the protection or muscle to operate internationally.

The local labor employed by the multinational corporation usually becomes a local elite in the subsidiary offices, their futures dependent on the growth of the corporation there. (Wells:1977) Their loyalties become supranational as their job security and promotions are controlled by the parent organization. The duties of a corporate executive are defined by a corporate chairman as follows:

He must set aside any nationalistic attitudes and appreciate that in the last resort his loyalty must be to the shareholders of the parent company and he must protect their interests even if it might appear that it is not perhaps in the national interest of the country in which he is operating. (Tugendhat:1972:5)

Such vested interests are part and parcel of being a member of the Church's hierarchy as well. Cardinals, Archbishops and Bishops orient their outlook to the corporate good. The lower levels of the priesthood largely identify with the local population. With its system of job tenure, and advancement based on seniority, a "local" with aspirations to rise strictly conforms to the home office, Rome's, dictates, even if they contradict the will of his local parishoners.

If the theory that the larger an organization becomes, the less responsive it is to local demands and needs, is correct, the situation is exacerbated when an organization, 
secular or religious, operates globally. Scheer (1974:101) asks if a New York executive sitting in his Wall street office is worried about the needs of a third world developing nation with a lower GNP than his own company's yearly sales. The tight centralized control exercised by the Vatican is viewed with the same consternation. In February of 1972 Cardinal Alfrink of Utrecht, Holland went on television to criticize the interference and medaling of the vatican in local decisions there. The choice of the diocese to be made bishop was over-ridden by Rome. Feelings were running high and threats were made of withholding money from the church until the Vatican became more responsive to the Dutch dioceses. (Economist: $1972: 46-47$ )

Several years ago pope John XXIII had directed that every Cardinal who participated in the election of a Pope must also be a Bishop. Such an action would have helped to depoliticize papal elections and loosen curial controls. Upon his death, Pope Paul VI took up the proposal and announced he was considering adding fifteen representatives elected by the synod of Bishops to the papal conclave. But during the 1974 meeting of the Synod of Bishops the African, Asian and Latin Americans took control and began to inculcate their program to end European domination while promoting their own. These bishops would have figured largely in the election of the chosen fifteen. However, Pope Paul at this point retracted his consideration of the establishment of bishop-electors and restricted voting rights to Cardinals only. (MacEoin:1978:xv-xvi) 
Top executives of global corporations and corporations themselves are viewed as "citizens of the world", supranational, operating with an eye to what is good for the corporation. With the world as their marketplace, business is conducted with associates promising the greatest dividends.

In essence, the structural configuration of global corporations is that of a main office or headquarters exercising tight control over their subsidiaries. Headquarters establishes the guidelines by which its affiliates shall operate and activities are easily monitored by rapid transit and mass communications. It is possible for the head office to intervene in local affairs when the overall corporate welfare is jeopardized, besides monitoring their international investments on a daily basis. The Vatican exercises this same sort of authority as it retains ultimate control in the naming of local Bishops and Cardinals. It can and does exercise the power to countermand dictates of the various national dioceses and issues its mandates concerning all facets of the church from its Rome offices.

Multinationals frequently protest that their local affiliates are independent entities and the Catholic Church maintains this position also. This neutral stance affected by global corporations is indicative of their concern for their local subsidiaries. A strong political stance might be favorable in one sector of the world while proving to be a handicap in another. (Levinson:1971:150) The Catholic Church opposes Communism on ideational grounds. However, the Vatican 
has not been outrightly aggressive in recent years but guarded in its relations with the communist bloc so as not to aggravate the condition of Church members there. Secular corporations are also opposed to Communism but on practical grounds. Nevertheless, both have reached agreements with several Communist governments with advantages accruing to both sides of the exchange.

These global corporations look at a world map without national boundaries and operate in all types of political systems. Global corporations frequently assert their "statelessness" (Barnet \& Muller:1974:16) and corporate presidents are hopeful for a future when headquarters is a "nerve center ...probably a temporary command post in a tax haven or an island." (Levinson: 1971:152)

It is the contention of this thesis that such an entity already exists, the Vatican City State (albeit its landlocked condition). As a religious institution with a global outlook, the bureaucratic structure of the Catholic Church must maintain it as a viable transnational actor. This structure is supported by a financial power base protected by the sovereignty accorded the Vatican City state which has endowed it with a power commensurate with that of other present-day global corporations.

\section{Organizational Structure}

Because of the Catholic Church's unique sovereign headquarters, its organization reflects that of both multinational 
corporations and nation states. The framework of the Church is designed along the lines of a corporate structure with 9 congregations of cardinals, 3 apostolic tribunals and 5 departmental offices. (See Table 1.) These congregations, tribunals and offices are grouped under the heading of the Roman Curia, the Church's power elite. The sacred Congregations are like a series of interlocking directorates. Most Curia Cardinals sit on four or five. Many cardinals are listed as members, but are stationed far away so the real power over the congregation is controlled by the curia cardinals who attend regularly. Each department is headed by a cardinal resident in Rome who is almost always elderly and of Italian descent.

The Pope and his college of cardinals have almost full power over the church. This power is shrouded in secrecy as the first official act of a Curial candidate is to swear an oath of secrecy concerning the operations of his office--the higher his position, the more strictly guarded is the secrecy. This secrecy is also reflected in that despite the fact that the Vatican is a sovereign state it does not publish a budget. Accurate financial statements on the total current holdings of the Church are not available to the public. Multinational enterprises are secretive about their operations and are reluctant to divulge information they may feel is political in orientation or damaging to their corporate image. (Tugendhat:1972:IX)

The high degree of power centralization in the catholic Church is a desirable quality in the corporate business world. 
TABLE 1

THE STRUCTURE OF THE CATHOLIC CHURCH

College of Cardinals

The Pope

State Secretariat and

Council for Public Affairs

Temporal and administrative power

1. Prefecture for Economic Affairs

2. Administration of H.S. Patrimony

3. Institute for Religious Works

4. Governor of Vatican City controlling:

a. Technical, financial and health services

b. Swiss Guards

Palantine Guards and Gendarmerie

c. Vatican Museums and Library

d. Vatican radio

e. Vatican observatory

f. Villa of Castelgandolfo (Papal summer retreat)

Congregation for the upkeep of St. Peter's
Spiritual, judicial and doctrinal power

Congregations for the: Doctrine of the Faith Oriental Churches Bishops

Discipline of Sacraments Saints

Clergy

Religious Orders and

Secular Institutes

Catholic Education

Propaganda Fide

Tribunals:

Apostolic Penitentiary

Sacra Rota (of appeal)

Apostolic Signatura (of cassation)

Permanent commissions and secretariats of various kinds

Apostolic Nuncios and Delegates

Bishops and ordinaries of the dioceses and of

other ecclesiastic jurisdictions

The clergy

(Pallenberg, p. 78) 
Corporate presidents who long to be free of national governments (Barnet \& Mulier:1974) must envy the man who becomes Pope, who loses his name and most civil ties that bind him to his native country.

The Pope's personal income is based on contributions to be used at his own discretion and unlike other corporate executives, the amount of his salary is not disclosed.

Popes have traditionally been Italian, but like secular corporate directorates the executives of the Roman Curia have been pressured to internationalize top management levels. Since the present Pope is of Polish descent, native locals in other subsidiaries are likely to hope for easier acceleration within the Church hierarchy.

Multinationals that fail to promote competent employees from local subsidiaries find that many of their best men leave. (Tugendhat:1972:202) This has occurred within the ranks of the Church's priesthood which has been plagued by a marked decline for several decades. The decline in seminary enrol1ment has been attributed to increased disenchantment with the Church's bureaucratic policies of longevity and seniority which are comparable to those of the U.S. Senate. Top management levels may not have been internationalized, but both secular global corporations and the Catholic Church allow their local affiliates to be run by the local population capitalizing on the popular phenomenon that people identify with their own. 
In describing the administration of the Papacy,

Vatican commentator Avro Manhattan writes:

Her administration is unique. Although a Church, she is at the same time a government. Although a mighty religious institution, she is also a mighty political presence and a major economic center. Although her officials are drawn from many nationalities, when acting as a member of her government they have none; while speaking the major languages of the world, she issues her ordinances in one which only a few can understand. (LoBello: 1968:80)

If "multinationals see the ideal top management as a close-knit group of men who understand each other absolutely" (Tugendhat:1972:195) the multiple languages necessary for global business are a major obstacle toward internationalization. The Vatican, however, has its own "company" language, Latin .

In dealing with its foreign affiliates, multinationals are just beginning to develop their own foreign policies, whereas the church as a sovereign state maintains its own duly recognized state department. Newly established nations frequently seek out papal recognition and a nuncio stationed in a country with a difficult government is an important factor for he has direct access to the head of state. The vatican maintains papal ambassadors called nuncios or apostolic delegates in most of the countries in the world. These diplomats send frequent reports to the Pope's Secretary of State, his right-hand man, who coordinates incoming news bulletins and prepares daily briefs for the Pope. The 1,500 Bishops stationed around the world also send periodic reports to the Pope concerning spiritual and economic questions. 
Bishops are required to make periodic personal visits to the Holy see for private audiences with the Pope. Important messages can also be sent to the Vatican by cable or transmitted by radio. The Vatican Radio issues daily news bulletins in thirty languages including Latin and Esperanto, the international language of this century. (N.Y. Times:1976Ja5,15:I) The Vatican Radio also broadcasts daily message to nuncios, delegates, cardinals and other religious groups the world over and often in a code understood only by the receiver. (LoBello: $1968: 87$ )

This tight centralized secrecy, characteristic of so many Vatican operations, grants more freedom to control informational input and output than most other multinational enterprises are allowed to exercise. The executive management of the Church does not have to answer to stockholders or to a national government and their priestly robes are able to mask a myriad of non-religious activities stamping them with God's seal of approval, the ultimate mark of legitimacy.

\section{Financial Base of the Catholic Church}

The Vatican offices dealing with financial affairs are the Administration of the Holy see Patrimony, the Institute for Religious Works (the Vatican Bank), the Prefecture for Economic Affairs and the State Secretariat. The Administration of the Holy see Patrimony was created in 1968 by Pope Paul VI. It absorbed two formerly distinct offices, the Special Administration and the Administration 
of the Holy See Properties. Theoretically, the latter was the wealthiest office since it includes art works and other physical assets considered priceless which are owned by the Vatican. The focus of this paper, however, is on the fluid capital which is handled by Vatican financiers.

The Special Administration had been created in 1929 by Pius XI to administer funds given to the Vatican by Mussolini as specified in the Concordat of the Lateran Treaty. In return for recognition of his government, Mussolini agreed to give 90 million dollars to the Vatican in compensation for the confiscation of the Papal states in 1870. Forty million dollars was in cash, the remaining $\$ 50$ million consisted of government bonds which yielded 5-6용 interest yearly. The Concordat between the Vatican and Mussolini also gave the Church full control over all entities operating under the name of Catholicism. These "ecclesiastical corporations" were and are exempt from tax and import duties and its members are granted diplomatic imrunity. (The Vatican City State was duly recognized as an autonomous entity and as such affords its Cardinals and diplomats Vatican passports.)

The Special Administration, created to oversee the proper investment of these funds, answered to no one, published no fiscal reports, paid no taxes and had the freedom accorded a diplomatic entity complete with its own information bureau. Lay financier, Bernardino Nogara, was appointed by Pius XI to head this office which he did singlehandedly until his death in 1958. Since that time the Admini- 
stration has been largely under religious control. The Special Administration was run by Cardinal DiJorio from 1958-1967. He served as assistant, secretary, then head of this office. He worked with lay financier and a former director of the Credit Suisse de Geneva, Maillardoz, where the Vatican has at least two accounts. (Lobello, 1968, p. 22) When Paul VI merged the two offices, he appointed Cardinal Amleto Cicognani, his secretary of state, as its head. When he was replaced by Cardinal Jean Villot as secretary of state, Villot also succeeded him as head of the Administration of the Holy See Patrimony. Villot died in March, 1979 and the current Secretary of State and head of this Administration is Italian Cardinal Casaroli.

The Administration of the Holy See Patrimony is divided into two sections, ordinary and extraordinary, corresponding to the former Administration of the Holy See Properties and the Special Administration. Mgr. Gasparre Cantagalli, who was already in charge of state secretariat funds was appointed head of the ordinary section. Businessman Marquis Henri de Maillardoz, headed the extraordinary section until his retirement when he was replaced by Italian banker Benedetto Argentieri.

The Prefecture for Economic Affairs, also created in 1968, was theoretically to be a "Budget Office." All other departments within the Church, except the vatican Bank, were to submit their budget report each year to Cardinal Vagnozzi, head of the Prefecture. He in turn would design a composite 
picture of the Vatican's financial affairs and submit this to the Pope.

This authority, however, has remained largely unexercised, due to the general reluctance to reveal any financial information at the Vatican. This secrecy also characterizes this office as the funds that it manages are deposited mainly in Swiss banks in numbered accounts. (LoBello:1968:118)

The Vatican Bank is supervised by a committee of cardinals among whom is Cardinal Guerri, who once headed the extraordinary section of the Administration of the Holy see Patrimony. Bishop Paul Marcinkus of Chicago is the bank's secretary. He and Cardinal Guerri are regarded as the "brains" of the Vatican empire. (MacEoin:1978:206) There have been several lay members on the board of this bank including Luigi Menini who has represented the Vatican's interests in several large Italian companies.

Menini is one of a core of Vatican lay elite who are placed on directorates in companies in which the vatican has invested. (See Table Two.) Menini has been on the boards of Immobilaire, an international building consortium, the Vatican controlled Swiss branch of the Banco di Roma and the Banco di Santo spirito. He also has been vice president of the Institute Centrale Finanziari, and has been on the board of CIM, a large chain of stores and supermarkets. (Pallenberg:1971: 101-102) These are a few of his more outstanding achievements. 
TABLE 2

VATICAN PORTFOLIO (ITALIAN HOLDINGS/VATICAN REPRESENTATIVES)

Banking and credit Companies

Banco di Roma - Menini, Spada, Guilio Pacelli

Banco di Santo Spirito - Menini, Sacchetti, Spada

Instituto Centrale Finanziari - Menini, Spada

Banca Catolica del Veneto - Spada

Istituto Bancario Italiano - Spada, Pesenti

Credito Comerciale di Cremona - Spada, Pesenti

Societa Meridionale Finanziaria - Spada

Banca Provinciale Lombarda - Spada, Pesenti

Banco di Roma per la Swizzera - Guilio Pacelli

Banca Privata Finanziaria - Sindona

Credito Italiano

Banco Ambrosiano of Milan

Piccolo Credito Bergamasco

Credito Romagnolo

Banca San Paolo

Banco di San Geriniano

Banca Comerciale Italiana

Building and Construction

Immobilaire - Menini, Sacchetti, Marcantonio Pacelli

Vianini. - Spada

Finsider - Spada

Pozzi - Marcantonio Pacelli

Condotte D'Acque - Sacchetti

Italcementi - Carlo Pesenti, Spada

Tosi Franco - Pesenti, Spada

Insurance

Riunione Adriatica - Spada

Assicurazione Generale - Marcantonio Pacelli

Campagnia Rias - Carlo Pacelli

Utilities

Italgas - Spada, Guilio Pacelli

Montecatini Edison

Pharmacy

Istituto Farmacologico Serone - Guilio Pacelli

Transportation

Lancia - Spada

Shell Italiana - Spada

Alfa Romeo

Textiles

SNIA -Viscosa - Spada

Finmare

Retailing

CIM - Menini, spada

Investment Firms

La Centrale

Bastogi 
Massimo spada, another Vatican consultant, also has been on the board of CIM and the Instituto Finanziario Centrale. Some of his past positions include president of the Banca Catolica del Veneto, and a position as president, managing director or board member of Italy's largest insurance companies. He has also been vice president of the Banco di Roma, vice president of the Instituto Bancario Italiano and of the Credito Comerciale di Cremona and on the board of the powerful financial holding company Societa Meridionale Finanziaria. He has also been on the board of Shell Italiana, the Italian subsidiary of Royal Dutch Shell; and on the board of Italgas; president of Lancia, a large automobile factory; and president of Vianini, a building firm; was president of Riunione Adriatica Insurance; and is connected with a host of additional firms. (Pallenberg:1971: 108) One of his most important positions has been on the board of Finsider, a steel corporation, which is part of the Institute for Industrial Reconstruction (IRI) which is a massive state-controlled industrial complex.

The Marguis Giovanni Sacchetti is another important lay financier whose career pattern can be traced. He has been president of the Banco di Santo Spirito, on the board of Immobilaire, and president of condotte d'Acque, a big building and public works firm. (Pallenberg:1971:110) Sacchetti, Spada, and Carlo Pacelli have all represented the Pope on the board of the Italian Home Ministry's special fund for charity and the promotion of religion in Rome. Sacchetti, Spada, 
Pacelli, Mennini and the latter's brother Filipo have been members of the exclusive club of the Privy Chamberlains of Sword and Cape, one of the highest honors bestowed by the Vatican. They used to wear a special costume and sit in a place of honor during official ceremonies, but Pope Paul VI abolished the costumes and they are now referred to as the "Gentlemen of His Holiness" (Pallenberg:1971:111).

Another link between Italian business and Vatican capital is Carlo Pesenti who controls Italy's cement industry. Italcementi is one of the world's largest producers of cement. He also has his fingers in the vatican pie. He has been on the board of the Credito Comerciale de Cremona (Spada is vice president). Pesenti and Spada are both on the board of Tosi Franco, which manufactures boilers, and of the Banca Provinciale Lombarda.

The Vatican has traditionally engaged in a strong degree of nepotism and the three Pacelli nephews of Pius XII are a case in point. Briefly, Prince Marcantonio Pacelli has been on the board of Immobilaire, president of the Panatanelia and Antonio spaghetti companies, the A. G. Insurance Company and Pozzi, which deals in sanitary appliances. Guilio Pacelli has been on the board of the Banco di Roma and president of the Banco di Roma per la Svizzera the Swiss branch of the Vatican-controlled Banco di Roma. He has also been vice president of Italgas and is president of the Instituto Farmacologico Serone, one of the biggest pharmaceutical companies in Italy which manufactures oral contraceptives, 
labeled "Luteolas", prescribed as a cure for gynecological complaints. Carlo Pacelli was present on nearly all Vatican offices dealing with finance, legal advisor to Holy See Patrimony, and was president of the Campagnia Rias, an insurance firm. (Pallenberg:1971:100-101)

The preceding overview of the activities engaged in by the lay business associates of the Vatican is by no means an exhaustive list, but it serves as an indicator of the depth of the Vatican's involvement in the Italian economy.

\section{The Church/State Relationship in Italy}

Of all its foreign relations, the country the Vatican is most involved with is Italy. Estimates of the amount of Church investment in Italy's stock market, banks, real estate, and other business enterprises are as high as three-quarters of the total fluid investment capital administered by the Vatican. This investment policy was caused by the creation of a highly favorable investment climate created by Mussolini and the conditions of his concordat. The granting of tax and import duty exemptions has obviously saved the church millions of dollars. The according of diplomatic immunity to executives of all "ecclesiastical corporations," including church institutions which were strictly financial undertakings, also helped to create a situation which would be highly attractive to any global corporation.

Bernardino Nogara, administrator of the capital endowed to the Vatican, capitalized on this highly favorable environ- 
ment and on his background as a former vice president of the Banca Comerciale Italiana, and initiated investment policies which forged the present day Vatican portfolio. Italgas was one of his first projects. It began as a small corporation of six small gas companies which were floundering in 1932. With the help of Senator Alfredo Frassati and Marquis Francesco Pacello (brother of Pius XII), the Vatican took control. (LoBello:1968:70). Today it is the sole supplier of gas to many Italian cities and the vatican remains the controlling stockholder.

Under Nogara's leadership, the Vatican took control of SNIA-Viscosa Company which makes viscose fibers and rayon, and the Saici Company which manufactured cellulose. SNIA-Viscosa holds a "considerable quantity of stock in Colonificio Veneziano", a Vatican-controlled cotton plant. SNIA also owns two textile companies in spain, two in Brazil, and one each in Luxemburg, Argentina and India. The Vatican is also a "heavy stockholder" in these companies. (LoBello: 1968:102-103) In London, the financial agent for SNIA Viscosa is the Hambros Bank whose Italian affiliate is the Vatican controlled Banca Privata Finanziaria. (Pallenberg:1971:161)

Pozzi, which specializes in bathroom fixtures, is one of the Vatican's biggest companies. Vatican business strategy is exemplified by the following occurrence. During the 1960's, Pozzi was in financial straits. In 1964, Mgr. Casaroli, a secretary of state official, specializing in Communist countries, negotiated an agreement with the government of Hungary 
and during the proceedings convinced them to buy appliances from Pozzi. (LoBello:1968:103)

The Vatican is very active in the world of private enterprise, but it also has a considerable hold on enterprises which are operated by the state government of Italy. At the end of World War II, when the Italian economy was in shambles, the government organized the Institute for Industrial Reconstruction. The government took control over many firms in the areas of banking, shipping, manufacturing and communications. IRI companies number well over one hundred and were and are financed by bonds floated on an open market. These bonds are government backed, tax free and anonymous. (LoBello: 1968:107) It has been established that the Vatican was endowed with 50 million dollars worth of these bonds in 1929. Since then, however, the exact amount of purchases by the Vatican is not known, but areas where their interests are the heaviest and reportedly known include the following enterprises. The steel corporation, Finsider, is considered to be the backbone of the IRI corporation. When the IRI absorbed the firm over thirty years ago, it had an annual output of one million tons of steel. When the help of vatican funds, it increased its output more than tenfold. It has joined the European coal and Steel Community and is now considered among the top ten of the world's leading producers of steel. (LoBello: $1968: 108)$

The biggest Vatican project in the IRI was Italy's number two second leading car manufacturer, Alfa Romeo. Italy's big- 
gest industrial engineering concern, Finmeccanica, has also received considerable support from the Vatican. Finmeccanica is involved in the designing of air and rail transports, heavy machinery, and munitions; extending tenaciously into almost every aspect of industry that requires engineering. LoBello (1968:111-112) reports that: "Aided by heavy Vatican investments the Finmeccanica group has shown remarkable progress since 1959, when its annual profits began to rise from $\$ 185.6$ million to the present day figure of over $\$ 420$ million (and its exports from $\$ 41.6$ million a year to nearly $\$ 100$ million)."

The Vatican is also in the shipping industry. "Finmare," another IRI affiliate, serves nearly $70 \%$ of the passenger service in the country. It is reported that the two transatlantic luxury liners it owns, the Rafaello and the Michelangelo, were financed by Vatican money. (LoBel1o:1968:112)

In the banking arena of northern Italy, the Vatican reputedly owns the Banco Ambrosiano of Milan, the Banca Provinciale Lombarda, Piccolo Credito Bergamasco, Credito Romagnolo, Banca Cattolica del Veneto, Banco di San Geriniano e San Prospero and Banca San Paolo. The Vatican also has a "heavy" interest in thirteen other large banks and minor holdings in sixty-two others. (LoBello:1968:116) In southern Italy the Vatican or the local church owns all the banks outright. In the case of parish church ownership, the local bank is audited by a roving Vatican financier on a regular basis. 
The Vatican's cement company, Italcementi, has a financial institution called Italmobilaire which bought eight banks in 1967 and merged them forming the Istituto Bancario Italiano (I.B.I.). Headed by Carlo Pesenti, it ranks among the top twenty Italian banks. (LoBello:1968:117)

The Vatican is also in the insurance business. Two of the leading Italian firms, Assicurazioni Generale di Trieste e Venezia and the Riunione Adriatica di Sicurta are owned by the Vatican. The latter is linked to the Credito Italiano which is Vatican controlled. Assicurazioni Generale has retained several Christian Democrat Senators on its board of directors which has helped to secure lucrative government contracts involving government industries and foreign customers. (LoBe1lo:1968:122) Assicurazioni Generale is tied to the Banca Commerciale Italiana, which the Vatican controls, and has a "large amount" of stocks in Montecetani Edison and vice versa. (LoBello: $1968: 122$ )

Montecatini Edison is not just a general electric company. It also deals in mining and metallurgical products, pharmaceutical products, fertilizers and textiles. Bernardino Nogara served on the board of Montecatini for many years before it merged with Edison in 1966. This merger increased sales from $\$ 683.9$ million to $\$ 854$ million and the net profit from $\$ 62.6$ million to $\$ 66.1$ million in one year. The exact amount of Vatican involvement in this corporation is not known, but its investments are viewed as "substantial". Montecatini Edison also operates internationally with associates in Holland, the U.S., India, Spain and Brazil. (LoBello:1968:100-101) 
In 1962, the Italian government nationalized the electric companies which further exposed vatican interests. Vatican associates, La Centrale and Bastogi, investment firms, had portfolios of several thousand shares worth millions of dollars in the following power companies: Lacentrale

had a portfolio of 8,235 shares (worth $\$ 24,801,600$ ) in the Selt Veldarno electric works and 8,417 shares (worth $\$ 25,153,600)$ in the Romana di Elettricita Company; Bastogi had 10,265 shares (worth $\$ 13,838,400$ ) in the Societa Meccanica Elettrica eletrei company, 6,407 shares (worth $\$ 8,441,600$ in the Finanziaria Adriatica company, 5,385 shares (worth $\$ 12,146,000$ ) in the S.G.E.S. company, 4,013 shares (worth $\$ 10,038,400$ ) in Edison, 1,137 shares (worth $\$ 4,782,400)$ in the Elettricita Sarda, and 996 shares (worth $\$ 2,659,200$ ) in selt Veldarno. Payments on these holdings, by way of indemnity installments are still being made by E.N.E.L. to La Centrale and Bastogi. (LoBello: 1968:134-135)

Despite the secrecy with which the Vatican cloaks its operations, both at home and abroad, the power of the Vatican vis-à-vis the Italian economy, its "host" country, is gradually becoming more apparent.

\section{The Vatican in Politics}

In describing the multinational phenomenon, scheer (1974:105-106) writes: "multinationals become multinationals to expand their technology, capital, patents, marketing techniques, and managerial skills outside of their national boundaries." He goes on to say that the real institutional significance of the corporations in modern society is that basic power knows no separation of politics from economics. Power to make a profit means power to manipulate labor, capital, expectations, fears (culture) and the political process. It 
means being able to control resources, government regulation and the pattern of family life.

This description of global corporations can be directly applied to the political relationship between the Vatican and the Christian Democrats. The Vatican has played politics to keep the Communists disenfranchised as much as possible. If they had come to power after the end of World War II, the Vatican would have lost everything.

The Christian Democrats are a resurrection of the old Popular Party founded in 1919 by Don Luigi Sturzo, a priest. It was reorganized and funded by the Vatican and has ruled uninterruptedly since 1945.

The Catholic Action groups found in every diocese in Italy are viewed as the backbone of the party. Catholic Action was organized by Pius XI. Ostensibly, its purpose is for Catholic education and charity, but it is also politically active and the group works toward the promotion of the church's social, political and economic goals. Catholic Action is able to influence bureaucratic appointments and to secure its members positions of directorates of IRI firms. The committees have also been known to work together to defeat a Christian Democrat candidate who has not cooperated. This lay organization has given a tremendous political power base to the Pope, allowing him a pervasive influence over Italian culture, and the Italian social and political lifestyle.

The interlocking directorates between Vatican associates in banking, real estate, state-run industries and private 
industries are typical of the business procedures used by secular multinational enterprises. There is overlap between multinational corporations' interests and those of state governments, especially the host country's interests. (Tugendhat:1972:1) However, these corporations are concerned above all with their own vested interests and I am suggesting the Vatican can be seen as operating in the same manner. The Vatican is said to be one of the world's biggest shareholders. Because stock reports and annual budgets are unavailable due to the Vatican's code of silence, only approximate assessments of its total worth are available. They have varied from a low of $\$ 4.8$ billion from the conservative Economist to the Times' figure of \$l0 billion with other sources putting the figure well above the \$25 billion mark. Internationally, it reportedly owns shares in GM, Shell, G.E., Bethlehem Steel, International Business Machines and TWA, and also maintains a sizable gold reserve in Fort Knox. (Pallenberg, 1971:160) The disparate holdings enjoyed by the Vatican suggest that it operates as a behind-the-scenes agent helping to support the global corporate world system. 


\section{GLOBAL FINANCIAL DEALINGS OF THE CATHOLIC CHURCH}

\section{Corporate Planning}

In charting the growth of a multinational corporation with its resultant challenge to national political power, Levinson (1971:146) posits a three-stage model. They begin as large national companies doing some business abroad in the first stage; in the second stage, they begin to outgrow their home base doing a significant part of their business internationally. Finally, they are international enterprises producing and selling primarily to a global market.

Such has been the historical development of the Catholic Church with the modern Church representative of the third stage, a true global corporation. In describing this resultant global entity, Levinson (1971:146-147) says:

Character, currency and management are global without binding commitments to any one state. Headquarters plan personnel, investments and sales to be conducted on a worldwide basis.

Global corporations look at a map of the world without national boundaries with an eye for any hospitable market, whether "communist," "capitalistic," "developed," or "undeveloped."

The Vatican's financial power and presence have infiltrated nearly all aspects of the Italian economy, but I propose to demonstrate in this chapter that the vatican has not 
limited itself to investment relations with its "host" country and also occupies a significant place in the global economic arena.

For an organization or business to grow from being national in scope to international in outlook requires careful "corporate planning." Basic to such a planning strategy would be an "enduring philosophy" intrinsic to the nature of the enterprise itself. The organization would have to allow for a certain latitude in flexibility with its dealings with other world agents. The organization's structure would have to be carefully delineated and maintained. Finally, the planning itself would have to be "superior" in aptitude. (Steiner: 1966:26-29)

These basic ingredients to planning a multinational enterprise are also characteristic of the Catholic Church. First, its ideology has remained largely unchanged since its inception. The rules and format given to the founders of the Church and their recorded scripts have served as a constant guideline to church policies, committing it to certain goals. Manifestly, of course, the Church's goals are religious, but as it occurs in so many organizations, its goals may shift over time (Blau:1971) and within part of the organization. The emphasis in this paper is on the Church's secular features, or "latent" economic goals and how they are similar to other global corporations. As for the second characteristic of flexibility, the church has shown itself to be markedly adaptable in its dealings with hostile and friendly 
environments around the world. Finally, the Church's directorate, the Curia, is generally viewed as utmostly concerned with its own self-preservation and the protection of the rights and privileges the title of "Prince of the church" endows. Members of the Church's "power elite" generally require an intensive education within the Church which begins at the young age of ten or eleven and as they ascend the bureaucratic hierarchy, the intrinsic policies of Church diplomacy and government are well mastered.

Multinational corporate planning also requires a position of "director of planning" or "chief financial controller" to be created. He reports directly to the chief executive, (Steiner:1966:39-44) and he is the one who develops a bird's eye view of the "economic, operational and financial" state of the corporation as a whole. He must constantly monitor the environments in which his corporation is involved. He develops goals and "diversification targets" for the firm, and, finally, administers his own "creation."

Within the Catholic Church, such a person was Bernardino Nogara. The knowledge of banking and investment practices he brought with him to his post of executor of the funds of the Special Administration forged and maintained the Vatican's fiscal policies to the present day. When he died, he left behind his credo of business policies to be followed by his successors. (LoBello:1968:30)

1. Increase the size of your company because it will be easier to obtain funds from the capital market. 
2. Increase the size of your company because highcapacity installations allow the reduction of industrial costs and the subdivision of overall expenses.

3. Increase the size of your company because it is possible to economize on transportation.

4. Increase the size of your company because it will allow capital to be invested in scientific research that can bring tangible money results.

5. Increase the size of your company because the personnel can be organized and used in a more rational manner.

6. Increase the size of your company because fiscal controls on the part of government become advantageously difficult.

7. Increase the size of your company because it is necessary to offer customers the best technical product.

8. Increase the size of your company because this will engender more increases. (LoBello:1968:30)

Both the Catholic Church and multinational corporations pattern their actions after the business ethic, growth is good. Growth must be the result of any exchange whether foreign or domestic. This concern with growth by the multinational corporations has frequently been criticized as obsessional. Such aspirations by the church are deemed particularly inappropriate.

\section{Global Banking}

Modern finance management requires global corporate policies. Corporations such as Ford, GM and shell maintain corporate money managers to optimally invest their funds on the "hot money circuit." (Levinson:1971:87) Vast sums of money are able to travel around the world without actually 
shifting places. The world system of global banking allows for crediting, investing and borrowing without the usual barriers posed by nation states. These "interlocking directorates between banks and business make the money market highly concentrated and structured...Montedison, SNIA, ENI, IRI and Fiat have interlocking ownership with banks"... and the vatican..."making it difficult to distinguish between them." (Levinson:1971:195)

This tightly knit world market is assessed as the catalyst behind the increased growth of the world money market, despite high rates of recession and inflation suffered by many of the developed countries during the last decade. For example, the Banco di Roma, and the Credito Italiano, and the Credit Suisse, all Vatican associates, show a "healthy growth rate" despite an ailing Italian economy. (Levinson:1971:198) Corporate clients can also conduct their business where market conditions are the most favorable and quickly move on if the economic and/or political climate changes.

Global corporations exchange currencies as a matter of policy to avoid the claims of national governments on their profits. (Levinson:1971:144) In response to this practice, banks operate multinationally to service the needs of this special group of customers. Until recently, most major banks operating around the world have been American, but the trend is now toward a true international banking system composed of banks without national affiliations. 
In "joint venture banking," large, unaffiliated banks buy up smaller banks merging them into a new firm or linking them in a completely new multinationally based financial undertaking. In Italy, the "3 R venture Fund" has been formed consisting of the Vatican, the Rothschilds, and the Rockefellers. The Societe Franciere Europiene in Paris is owned by the Barclays Bank of the United Kingdom, the Bank of America, the Banque Nationale de Paris, Dresden Bank of Germany, the Banco Nazionale del Lavoro of Italy (which is linked to the Vatican and "finances Italian firms working abroad"...(Pallenberg:1971:114), the Dutch Algennense Bank and the Bank of Brussels. (Levinson:1971:144) Global corporations require such enormous amounts of money that such multifarious banking enterprises were requisite to float the desired amounts of capital.

\section{Multinational Corporations and}

\section{State Governments}

Multinational corporations are able to affect the rates of currency exchange by amassing or unloading large sums of a national currency. This often results in overriding a particular government's efforts to control its own economy. In playing the corporate game, multinationals : also often exert a strong influence on national economies by conducting business in one area as opposed to another. Economic decisions result in political pressures. The fact that the Vatican operates in this manner is evidenced in an article in the New York Times, F. 20, 1977, 4:1, 
reporting that Prime Minister Soares of Portugal, on a tour of the European Common Market, had a private audience with Pope Paul on February 19th. That day he received the Italian government's support for Portugal's entry into the European Common Market. John Paul II stated that he opposes a direct church role in individual countries" political lives. But in December of 1978, he sent a fact-finding mission to Lebanon and received black nationalist leaders from South Africa. John Paul II maintained that he will actively concern himself in political issues advocating a dialogue with Commist countries as long as they don't interfere with the Church.

The global corporations are assertive in their quest for dominance, but resist disclosure and regulation. The Catholic Church conducts its affairs in a similar vein. At the annual bishops' meeting in 1976, a report was circulated saying that "church" and "state" are on a collision course because of the overwhelming amount of government regulations being applied to churches and their agencies. John Cardinal Krol of Philadelphia cited "a mass of regulations, rules, licensings, inspections, directives and demands for information confronting the churches." (N.Y. Times:1976:N.14:,24:3)

Ever wary of national governments' demands for a share of their profits, corporate earnings are often reinvested in the corporation itself as a method of tax evasion on stock dividends. (Scheer:1974:113) This policy also ensures the continuous long-run growth of the organization as well. 
The Vatican has been engaged in evasive tactics for a number of years. In December, 1962, the Italian government passed a law assessing a 15 t tax imposed on dividend income received by foreign corporations from Italian investments. As a foreign investor, the Italian government insisted the vatican would have to pay. Outwardly, it agreed to honor this law, but negotiations were begun shortly thereafter to ensure its exemption. The Vatican threatened to divest itself of millions of its shares if its demands were not met. (Pallenberg:1971:123) To honor its request, the late Prime Minister Aldo Moro asked for a complete disclosure of the Vatican's portfolio. Naturally, this request was refused on the grounds that one government does not tell its financial holdings to another. (LoBello:1968:126) At this point it seems the matter died in a parliamentary committee until a change in the Italian parliament took place in 1968 and the new Prime Minister Giovanni Leone demanded that the vatican pay the required back taxes as well as current taxes due.

The liberal publication, L'Espresso, called the Vatican "the biggest tax evader in post-war Italy," positing that it owned one-fifteenth of the Italian stockmarket. (LoBello: 1968:128) Vatican spokesmen cited the Concordat's explicit tax exemptions and used the counter-argument that the Catholic Church is actually a "welfare agency."

The counterpart of this tax exemption can be seen in the framework of reciprocity in the wide contribution that the apostolic activity of the Holy see has on 
tourism, as well as the advantages Italy derives from the Holy See's stock investments which contribute to increasing the national income. (LoBello:1968:131)

In 1967, the tax, cedolare, was doubled to 30 percent and this the Vatican refused to pay. It is reported that Pope Paul VI made an offer to pay $\$ 7$ million to the Italian government, but whether or not the issue was finally resolved is not known (Gollin:1971:484) and I have been unable to find any accurate recent information on what, if any, taxes have been collected from the Vatican.

The stocks in dispute do not include the State bonds held by the Vatican which yield a tax exempt 5-6 percent interest. Ownership of these bonds is anonymous and subject to no controls. I'Osservatore Romano, the Vatican mouthpiece, expounded that the unassessed amount of money that the Vatican amassed was irrelevant because the money is "holy money, entirely earmarked for charity." (LoBello: 1968:130) However, the multibillion dollar stock portfolio held by the Vatican is not an irrelevant force despite the top executive management's disavowal of its pursuit of profits and the dollar figure with which it is accredited.

On April 2, 1975, the New York Times reprinted an interview from Europa, a monthly supplement published by Le Monde, the London Times, La Stampa and Die Welt, by Lamberto Furno with Cardinal Vagnozzi, administrator of the Prefecture for Economic Affairs. He dismissed assessments of the Vatican empire in the billions of dollars as "simply crazy" and maintained that the Vatican's global 
investments total less than $\$ 120 \mathrm{million}$. He said instructions had been given to avoid investing in corporations "contrary to Christian morals and that the Vatican shunned any interest in companies that manufactured contraceptives and in any field which might be in conflict with the church's peace mission"--implying that the vatican held no stock in armaments. He also confirmed that the Vatican had recently switched investments from Italy to other countries, especially the United States. The interview did not mention the role played in the transfer of investments by lay financier, Michael Sindona, who was reportedly in the U.S. at that time. Sindona was wanted in Italy on charges of fradulent bankruptcy, forgery and other banking "irregularities."

A Vatican spokesman had said in January of 1975 that a "church based institution had suffered financial losses" caused by the folding of Sindona's financial organization. This admission that its institutions were affected by Sindona's fraud came on the heels of a previous announcement that there was a "cash flow" problem within the administration of the Church's finances and an "austerity drive" was planned forecasting cutbacks of the Vatican's 3,000+ employees. Vatican spokesman, Federico Alessandrini, denied that the losses were sizable in response to an interview with Massimo Spada printed in Rome's magazine, I'Espresso. Spada had said that Sindona had assisted the Vatican in many financial enterprises including the selling of some shares of 
Imnobilaire (the international building and real estate congolmerate responsible for the building of watergate) to the Rothschilds' Banque de Paris et des Pays Bas. Spada assessed the amount of losses suffered by the Vatican from Sindona's collapse at $\$ 55$ million. Spada, now retired, was once administrative secretary of the Vatican Bank and still sits on the boards of many companies representing the Vatican's interests.

In the interview, Alessandrini also insisted that the Vatican Bank was intended for the use of all Church officials and members and it was totally independent of the Holy See. He also mentioned that the Vatican Bank was picking up the tab on Sindona's losses. He admitted Vatican involvement in Finabank of Geneva and in the Banca Privata Finanziaria. Sindona was vice president of the latter bank and was once in control of the Franklin National Bank of N.Y. However, Alessandrini denied intimations by Spada that the Vatican engaged in foreign money speculation through them. (New York Times:F1, 1975:4:2) However, when the closing of Finabank was announced, Daniel Bodmer, secretary of the Federal Banking Commission, attributed its closing to "heavy debts" as a result of foreign exchange transactions that greatly exceeded the bank's $\$ 19.6$ million capital. It was also reported that the Vatican had maintained a "sizable block of stock" there. (New York Times: Jan. 8, 1975:51:2) 
Monitoring the internal transfer of profits within a global enterprise is extremely complex, even if the efforts are those of a state government. Scheer (1974:120) writes:

It is this 'being within the business environment' of a foreign country (rather than exporting to it) that is the key characteristic of multinational business. From this flows the power to manipulate governments, markets and prices, to beat competitors and increase sales and profits.

"Penetration" is the key requirement for doing business in the modern world economy--setting up business operations, finding "local labor," coping with local cultures, etc. Such has been the policy of the Vatican in relation to Italy.

The pervasive hold that the Vatican exercises over the Italian economy is revealed also by its rule as a wealthy real estate and land agent. The following excerpt from Atlas magazine (March 1977) which reprinted an article from L'Europeo cites various transactions which are viewed as typical Vatican proceedings:

On Dec. 4, 1970, the See sold the Antonelli Palace on Via Quattro November opposite the main office of the Banca d'Italia, to the same for $1.7 \mathrm{million}$. This building had come to the Vatican as a legacy from Countess Maria Emma Garcia della Palmira in 1932. The bank of Italy had occupied the 6 story palace up to the time of purchase paying $\$ 50,000$ in yearly rent to the Holy See. Neither the Bank of Italy nor the Vatican paid a dollar of tax on the transaction... ... On Dec. 11, 1974 the Papal See sold 16 acres plus the elegant villa names the 'Three Mills' where Loyola Univ. was situated to Minerva, Inc. of Rome for 2 million. At the time of the transaction Minerva was controlled by two fiduciaries of the Banca Nazionale del Lavoro and the Banque Nationale de Paries. The two banks also bought the adjacent two acres for $\$ 340,000$. The total of $\$ 2.3$ million eventually found its way into the coffers of the Vatican untouched by the Treasury... 


\section{Atlas also included L'Osservatore Romano's reply to}

this article. The defensive posture adopted by the vatican is strikingly similar to the tone and stance taken by other multinational corporations in the face of threats posed by labor, tax increases, etc.

So far as the Holy See's properties are concerned it should be evident that a large worldwide institution such as the Roman Catholic church needs a certain number of departments, comnissions, offices and organizations adapted to the growing needs of past decades. It follows that these organizations cannot conduct their work even on a minimal basis without building, personnel and financial resources.

This explains why apart from the extraterritorial edifices listed in the Lateran Treaty, the Holy see owns other properties. On those situated in Italian territory, real estate taxes are regularly imposed and deposited with the Treasury. Possible exceptions are due to charitable purposes...

One such "charitable organization" is a transmitting station owned by the Vatican Radio located in the city of Rome on "extraterritorial" land.

Why do institutions devoted to the public good inspire so much hostility? Do our critics want to oust from Rome the charitable institutions that inspire the sympathy and love of the entire world? This attitude merely leads religious institutions to think they had better relocate their main offices in other countries, which have shown the respect and consideration indispensable to their community-serving activities.

There is good reason to deplore and protest the irresponsibility of L'Europeo, which, not unlike other daily and weekly newspapers, distorts almost consistently all matters that concern the Holy See, the Vatican, and the Catholic Church. The magazine is preying like any cheap scandalmonger on the reader's gullibility, thus inspiring new forms of anticlericalism that may be worse than past outbursts. this kind of journalism, based on intentional misinformation and on perversion of the objective truth, borders on anticultural, moral aggression by narrowminded bigots. 
However, in the New York Times (December, 1976:5:1)

it was noted that reports of the Holy See's one-quarter ownership of the city of Rome, including extensive property around the Piazza Navora, the Collosseum, and the modern Parioli sections "did not seem scandalistic and appeared within reason" according to Vatican observers.

The flood of criticism directed at the Vatican's international and domestic business and banking practices has also reached the Vatican Bank, the Institute of Religious Works, itself. The Italian press accused it of "mercantile speculation from currency to high flying common stocks" and that wealthy Italians were escaping "tax and currency laws." Il Mondo charged it with "using the most unscrupulous channels that capitalism offers." The Bank is subject only to the Pope and as an "ecclesiastical corporation" benefits from the resulting immunities it is granted. This independence is resented by the press and some Cardinals. The objectionable banking practices of this organization were also headlined in the 1960's when the Italian press revealed that the Vatican had invested in the casino at Monte Carlo, the Beretta firearms concern and a Canadian producer of the Pill. (Newsweek, S. 25, 1978)

Current director, Bishop Marcinkus, sits on the board of the Cisalpine Overseas Bank which is involved in the Caribbean Eurocurrency market, another secretive organization. Eurocurrency markets are frequented regularly by multinational corporations to deposit funds not immediately 
needed for tax free interest, and as a haven for profits to escape the tax laws of countries in which the corporation does business. Eurocurrency markets also issue loans for new investments, the minimum being about $\$ 500,000$, but groups of cooperating banks are known to finance loans of $\$ 100$ million for a borrower. (Tugendhat:1972:159) The Special Administration is also linked internationally to other banking systems. "When the Holy see decides to buy or sell its Wall street shares, it conducts its business through the Bankers Trust Office in New York." (Pallenberg, p. 87) It is also linked with Morgan Guaranty Trust of New York, Rothschilds of London and Paris, Credit Suisse, and Hambros Bank of London.

The fact that the church, her bank and business practices have been in the limelight to such a degree has raised questions concerning the role of the church in the secular world. The Newsweek article previously cited quotes Vatican observer, Don Giovanni Ceretti, as saying that

the Vatican is financially dependent on the capitalistic system. It finds itself on the side of the capitalists in certain social conflicts. All that cannot but raise questions, particularly from younger churches. 


\section{RELIGIOUS IDEOLOGY VS. FINANCE}

\section{Catholic Church's Foreign Aid Policy and Diplomatic Relations}

During the last several years, there has been a rising demand that Church investment procedures become more aligned with Church teaching. Profit mongering and speculation are decried as antithetical to the ideology preached from the pulpit. The most vocal voices have been the press in bringing pressure to bear on top Church executives to affect a more positive posture toward "good corporations" which are "socially progressive" to reflect their market policy of "enlightened capitalism."

Atlas magazine (May 1970,19:15-6+) translated an article from L'Actualite, Paris which reads:

...the Church intends to review its ties to the poor people of the earth in a major economic offensive in Latin America. Supranational, accountable neither to a government nor to the public, the Vatican's holdings span the globe--largely untaxed and virtually unaudited.

The author, Simon Spivac, felt that

the Church will use its immense wealth and influence to displace the United States as Latin America's chief provider--and in the process unite a church driven by dissent under the banner of the new crusade: Will tomorrow's slogan in Latin America be 'Vatican Go Home'?

In April of 1969, the Vatican created the Special Fund for Latin America. Capital for this venture went into the Inter-American Development Fund called the Populorum Prog- 
ressio fund after Pope Paul's encyclical on the poor. The establishment of this fund was timely. After several years of hedging the Italian government on its tax payments, intense criticism by the media and threats to pull out of Italy, the Vatican did divest itself of shares in several major Italian firms. Its controlling shares in Immobilaire were sold to the Rothschilds and 20 percent of the shares in Condotte D'Acque were sold to Bastogi and 5 percent to the Banque de Paris et des Pays Bas. (Pallenberg:1971:166) The initial endowment to the Populorum Progressio Fund was \$100 million and there is at least a hypothetical connection between this money and the profits made on the sale of its stocks.

If the third world is the key to the Church's future, the enormity of such an undertaking might at least direct some attention away from the wheelings and dealings attributed to the Vatican's financial offices. Initial investments in education, welfare and social work are not profitable, but a spiritual authority that is "supranational" might be above suspicions associated with secular incoming corporations. With a long-term investment strategy in Latin America, the Church could continue the plan of "penetration," previously defined, and diversify into the more profitable areas of real estate and industry.

Already within the past decade, foreign missionary priests have formed approximately 150,000 comunidades de base (base communities) servicing the needs of the poor in 
Latin America which is the vast majority of the population. With the help of their religious leaders, the poor are becoming educated and politically aware. At the Conference of Latin American Bishops in Puebla, Mexico, last February, the Bishops report cited the communities as "one of the motives for joy and hope in the church and the focal point of evangelization, the motor of liberation."

Prior to the much publicized visit of John Paul II to Mexico, hundreds of cumunidad members from Netzahualcoyotl addressed a petition to the Pope outlining the squalid living conditions there. In this same slum of almost three million people, several comunidades banded together to protest rising bus fares as well as the filth of their environment. (Time, My. 7, 1979:88:1)

This is the "Church of the Poor" Pope Paul VI referred to in his encyclical Populorum Progressio. The opening words focus on the third world. He said it is the moral duty as well as in the long-run interest of the developed nations to help the undeveloped countries toward "an acceptable standard of life." He condemned the current practice in international trade of developed countries buying raw materials from the third world and selling manufactured goods to them in return. This practice caused the undeveloped countries to rely on their export crop or goods which have fluctuating market value while manufactured goods continue to rise in price, thus leading to no development on the part of the world's periphery. "In the end the poor always remain 
poor, and the rich become even richer." Paul continued his criticism focusing also on international banking practices:

...a system was created which considered profit as an essential factor of economic progress, competition as the supreme law of economy and private possession of the means of production as an absolute right, without limits or corresponding social duties. This unbridled liberalism led to a dictatorship...the international imperialism of money... One cannot condemn sufficiently such abuses... (Pallenberg:1971:28-29)

Condemning these abuses is precisely what the press and other Vatican commentators have been doing, but they are commenting on the practices of the Holy See itself.

Present Pope John Paul II has also placed high priority on the third world and the communist bloc following the initiative begun by Pope Paul. His recent encyclical, Redemptor Hominis, also attacks the issue of our consumer civilization citing the surplus of goods in the rich developed nations while the rest of the world goes hungry.

So widespread is the phenomenon it brings into question the financial, monetary, production and commercial mechanisms that, resting on various political pressures, support the world economy. These are proving incapable either of remedying the unjust social situations inherited from the past or of dealing with the urgent challenges and ethical demands of the present. (Providence Visitor:Mr.15, 1979:1:4)

The western world has not been the focus of Catholicism since Paul's reign. The last few Popes have made certain that their views on world issues have been widely heard by their use of TV broadcasts beamed the world over by satelite. They have been very keen on making an impact on the developing world. The vatican has figured largely as an arbiter of third world aid funds. In March of 1971, 
the Roman Catholic Conference in Hong Kong put together an Asian welfare package of the greatest magnitude ever. (Economist: 238:30+, Mr.20,1971) Africa was another of Paul's favorite development areas. In the summer of 1969 , he went to Uganda. On returning, he engaged then Mgr., now Bishop, Marcinkus, secretary of the Vatican bank, and then Mgr. Benelli, now Cardinal and noted foreign diplomat, in forming a private international syndicate to invest money in Africa. Marcinkus was to scout for possible prospects to enter into the venture. The initial capitalization was to be $\$ 50$ million. Willing banks, industrial corporations and private investors from the "have" countries could join the Administration of the Holy See Patrimony as shareholders in this fund. The returns might be low, but the "political advantages" and "moral dividends" high. Marcinkus and Benelli discussed the project with the Ford Foundation and Bob McNamara, head of the International Bank for Reconstruction and Development. Both agreed to join the venture along with several major U.S. banks and corporations. (Gollin: $1971: 486-487$ )

This practice of social progressivism was witnessed by Paul's activist foreign policies as well as those of the present Pope. Within the last several years the number of international bodies on which the Vatican is represented has steadily increased. Papal envoys have represented the Holy See at the United Nations, FAO, UNESCO, and the Atomic Energy Commission in Vienna, for example. (Pallenberg:1971:85) 
In 1971, while Mgr. Casaroli was signing the International Treaty Iimiting the Proliferation of Nuclear Weapons in Moscow, apostolic delegates to England and the U.S. were signing the same document. (World Politics:jl,1974:26:54259)

Both Pope Paul and Pope John Paul II have made repeated overtures to the governments of the Communist Eastern European bloc dating from Paul's first diplomatic visit to Hungary in 1963. Hungarian party leader, Janos Kadar, and the Polish leader, Edward Gierek, both met with Paul as recently as 1976, 1977 and 1978. John Paul's recent trip to Poland was avidly covered by the media and has generated much publicity and speculation as to the amount of power the small Vatican City State is able to wield.

Pope Paul adopted a policy of "aggiornamento" in order to at least be able to learn of the state of the Church behind the Iron Curtain and perhaps to gain concessions from the communist governments in the form of allowing freer access for Church leaders of these countries to Rome so that they could be brought up to date on current church policies and teachings. With this policy, it is also hoped the status of Catholics persecuted for their beliefs would improve.

Gestures of good will are also answered in kind. Veteran diplomat, Casaroli, top ranked in relations with Communist countries, has been well received several times through the last decade in Russia. He re-established ties 
between the Vatican and Yugoslavia. In return for recognizing the government, the Vatican was allowed to publish its religious literature freely and to expand its religious education program.

When Gromulka feIl in Poland, the new party leaders were open in their stance toward the Church hopeful of securing their support to bolster their position with the Catholic population. It was reported that Gierek of Poland had a lengthy audience with Pope Paul during which the Pope offered to make a "positive contribution" to the Polish people in return for a free hand in administering religious affairs in Poland. Poland has been in recent economic straits and Gierek was viewed as enlisting the Pope's support. Pope Paul stated that "the Church was not looking for privileges but only the right to be itself and the possibility of carrying out the functions proper to it without obstacles." Both parties were hopeful of mutual cooperation. (New York Times,D.2,1978:14:3). These same sentiments were echoed by John Paul II on his recent trip to Poland:

It is the church's mission to make man more confident, more courageous, conscious of his rights and duties, socially responsible, creative and useful. For this activity the Church does not desire privileges, but only and exclusively what is essential for the accomplishment of its mission. (Time, June 18,1979:29)

The Pope also told Gierek that

...church-state detente in Poland could be one of the elements in the ethical and international order in Europe and the modern world, an order that flows from respect for the rights of the nation and human rights. 
The Pope's advocacy of the human rights issue has been a central topic of his public addresses. In Latin America, he expressed strong support of social action there and it is evident that social action is becoming a cause celebre for the Church everywhere.

Church-state relations with Czechoslovakia have been the most difficult. Cardinal Beran of Czechoslovakia constantly and adamently fought with the communists about religious persecution. Czech president, Gustav Husak, found Mgr. Tomaseka a much more amenable prelate and when he was tapped for the red hat in 1976, the regime allowed him to go to Rome. Pope Paul then persuaded Cardinal Beran to step down so relations with the Czech government could be improved and Tomasek was appointed administrator of the see there. Upon his return, Husak wrote to them: "We are interested in a positive development of the negotiations with the Holy see. I take note of your desire to exercise a positive influence on these negotiations." (MacEoin:1978:169-70)

It has also been reported that a representative of the Pope met with the foreign minister of mainland China to discuss the possibility of renewing diplomatic ties. The Vatican might have to work within the conditions outlined by the Chinese government which includes Vatican acceptance of government appointed Catholic clergy there. If the vatican decides to work within these limitations, it would at least be able to assess the state of the Church within a nation it has had no contact with for years. 
The third world foreign policy of the vatican mirrors the sentiments expressed by Robert Stevenson, executive vice president of international operations of the Ford Motor Company:

It is our goal to be in every single country there is, Iron Curtain countries, Russia and China. We at Ford Motor Company look at a world map without any boundaries. We don't consider ourselves basically an American company. And when we approach a government that doesn't like the U.S., we always say, 'Who do you like? Britain? Germany?' We carry a lot of flags. We export from every country. (Scheer:1974:123)

Hard line policies are largely non-functional in diplomatic relations. The Vatican does not deal from a physical power base, but does possess significant economic clout and is greatly respected as a moral or spiritual authority. The staunch anti-communism attitude of Pius XII has been mellowed by his successors who believe in direct negotiations to achieve concessions. The vatican diplomatic corps is composed of a host of consummate politicians using a soft-sell technique by necessity in order to reach the hungry miliions in the world's market.

\section{Vatican Missionary Activity}

The Vatican pours miliions of dollars each year into its missions which are mostly in Asia and Africa. These milIions are distributed by the Congregation for the Propagation of the Faith in Rome. The money consists largely of private donations from lay organizations: The Congregation does receive some assistance from the Vatican Treasury, but not nearly enough to cover the needs of its clients. There 
are four agencies mainly responsible for the support of the missions which are controlled by the Congregation. The Pontifical Society for the Propagation of the Faith was originally founded in France and the head office later moved to Rome. The General Superior Council of the Society, consisting of priests and prelates from various nations, meets three times a year to decide on fund allocations and discloses total amounts collected. (Pallenberg:1971:132) The Society of St. Peter was founded to contribute to the training of native clexgy. (Pallenberg:1971:134) The Pontifical Society for the Holy Childhood contributes to the support of mission children. (Pallenberg:1971:136) These three agencies consist of lay membership while the fourth, the Missionary Union of the Clergy, consists of nuns, seminarists and other religious who contribute to the support of all missions. Other private, charitable organizations exist such as Misereor and Adveniat in West Germany and the Catholic Relief Services in the United States, but these are independent lay organizations serving mission areas of their own choosing. The Congregation for the Propagation of the Faith is regarded as the least secretive office of the Vatican due to its lack of dependence on the Vatican's coffers and its lay foundation and leadership. Where missionary activity has been prevalent, the Catholic population has been increasing significantly, especially during the last two decades. This increase is attributed to the creation of native priests and the naming 
of Asiatics and black Africans to top executive levels. Such action is commensurate with the Vatican's global strategy. Increased industrialization correlates with a wane in religious belief and practice so the furor in developing a "native clergy" in non-European lands is indicative of its long-term investment policy and intent to survive. Corporate goals for growth and long term planning allow any multinational organization a high degree of stability, largely unaffected by the cyclical ups and downs of the various "markets" around the world. Any decline in Church attendance in one area of the world, such as that attributed to the U.S. Church, is matched by a corresponding growth in another area. Developments of new world markets such as Eastern Europe, Africa and Latin America, assure relative and absolute increases for the Vatican's membership rolls and coffers.

However, these new churches have balked at the double image projected by the Papacy: world empire, yet calling itself the "Church of the Poor." Both Paul's encyclical Populorum Progressio and John Paul's Redemptor Hominis decrie the social injustice rampant throughout the world which both attribute to the economic world system. Despite these condemnations of capitalistic market tactics, the Vatican is deeply entrenched within this system.

Cardinal Vagnozzi, head of the Prefecture of Economic Affairs, in describing his duties and those of other curia finance overseers, says: 
We, the managers, want to improve investment performance... we are diversifying our investments over a large number of companies... We do not want to commit the Church to only a few companies, nor to a single investment field, nor even to a single national economy. The Vatican's investment policy remains basically conservative although the church's increasing needs mean that the balance between conservation and the need to increase income has been moving toward the need to increase income. (Pallenberg: 1971:171-172)

Vagnozzi seems to be paraphrasing the words of his predecessor, Bernardino Nogara: "Increase the size of your company as this will engender more increases." Corporate money managers are dedicated to the goals of profit and growth. The difficulty facing the Vatican is the reconciliation of these goals with its professed belief that "Blessed are the Poor" and its mission of spreading peace throughout the world. I suggest that this difficulty has arisen because the Vatican has aligned its actions with the multinational corporations' slogan, "Peace Through world Trade."

Sufficient evidence has been amassed to prove extensive Vatican involvement supporting the capitalistic international trade system despite protests by the Vatican that as a sovereign state it is neutral in its position toward the rest of the world.

As previously stated, recent Papal encyclicals have acknowledged the widening gulf between the "have" and "have not" sectors of the world's economy and have heeded the cry especially from the Church in Latin America for social welfare and redress for grievance long suffered. If the Church responds in its capacity of charity dispensing institution 
or as a self-interested investment corporation, remains a matter for future inguiry. 
IV. CATHOLIC CHURCH AS A MULTINATIONAL CORPORATION

Catholic Church's Multinational Operations

The Catholic Church has operated transnationally for 2,000 years. Its fortunes have ebbed and flowed, but it has survived the vicissitudes of the world's economic and political forces intact.

Maintaining the Holy See as a viable religious organization and political state requires vast amounts of money. Millions of dollars must be spent each year on the Vatican payroll which covers religious and lay salaries. Gardeners, stonemasons, and other service-oriented staff must be maintained as well as its postal service, army, ambassadors and their residences. Bureaucratic administrations must absorb a myriad of additional expenses incurred by its staff. The Vatican is estimated to have spent between ten and thirty million dollars during the Ecumenical Council of the 1960's. Papal envoys representing the Holy see at a variety of international organizations have to be supported. The Vatican Radio and L'Osservatore Romano also operate at the Vatican's expense. Extensive libraries and art galleries must be serviced. Buildings housing the myriad offices of the religious in Vatican City, as well as in Rome, must be maintained. 
The financial base which has developed to support the headquarters and subsidiaries of this enterprise I have suggested is comparable to that of secular multinational corporations.

\section{Multinational Corporation Characteristics}

Multinationals are seen as growing

at the expense of purely national corporations and becoming increasingly 'stateless,' complex, and intertwined with banks and government bureaucracies. They will continue to standardize global consumer tastes and cultures... The multinationals will continue to influence 'parent' and 'foreign' governments and formulate their own foreign policies and form noncompetitive alliances (like the oil cartel) to further their collective interest. (Wells, 1977)

This paper has presented evidence in support of all but one of these characteristics as being applicable to a study of the Vatican as a multinational corporation. Dr. Wells' contention that multinationals will "standardize cultures" and "form non-competitive alliances" is particularly noteworthy as it has special bearing on the church's current and future policies. The trend toward ecumenicalism initiated by the Ecumenical Council fifteen years ago which acknowledged the authenticity of non-Catholic churches and specified that the Roman Catholic Church should seek to unify itself with them, has been a giant step in the political thinking of the Church. For example, Pope Paul met with high priests of the Shinto religion in 1975 in what was the first official contact they had ever had. Paul told them the Catholic Church was seeking a dialogue with other faiths 
and complimented "the religious feeling and morality that (their) faith has transmitted to Japanese civilization and culture." (New York Times, F.28,1975,38:2) Earlier in the year, when Buddhist leader, Lama Gyala, visited Paul, the latter addressed him as "Your Holiness," which is the official title of the Pope. At that meeting, Paul made mention of the fact that the Ecumenical Council had expressed "admiration for Buddhism in its various forms." (New York Times, Ja.18,1975, $34: 1$ )

In his election as the first non-Italian Pope in over 400 years, Pope John Paul II is seeking to use his position as a catalyst for unification between the East and west. At Gniezno, Poland, earlier this year, he said to the crowds:

Is it not the intention of the Holy spirit that this Polish Pope--this Slav Pope--should at this precise moment manifest the spiritual unity of Christian Europe? Although there are two great traditions, East and West, to which it is indebted, through both of thern Christian Europe 'professes one faith, one baptism, one God and Father of us all.' (Time, June $18,1979: 30)$

This spirit of collegiality has resulted in the publication of the Common Catechism: A Book of Christian Faith which was written by both Catholics and Protestants. The book is viewed as the first of its kind since the Reformation. It consists of a mutually agreed upon ideology of beliefs and stresses the unity of thought achieved by the undertaking. In the Introduction, the editors write:

The various branches of the Church are no longer interested in what divides thern, but instead in how they are to understand and present the Christian faith in the world of today. (New York Times, March 17, 1975:1:4) 
In presenting the packaged product to the world market, it is more "performance minded," to quote Cardinal Vagnozzi, to present a united front. Missionaries or salesmen pooling fiscal and technical resources could plot a global investment strategy unhampered by the loss of revenue and expertise which competitive separatist policies of the past had engendered.

The internationalism intrinsic to the Vatican's fiscal policies and now its ideological stance also appeared to have begun to affect the church hierarchy as well. The top executive positions were an Italian stronghold until Pope Paul's election for in 1967 he appointed French Cardinal Jean Villot as his secretary of state. This position is second only to the papacy and controls the Vatican's fiscal resources. Paul did little else to revitalize the Curia and his successor, John Paul I, reappointed all Curial officials despite the fact that it is a newly-elected Pope's prerogative to name his own Cabinet. With the sudden death of John Paul I and his own unexpected election to the Papacy, John Paul II said he needed time to study Curial personnel and Cardinal villot was also asked to stay on during this time. Vatican observers speculated that if John Paul II changed this key post, it would be "indicative of how he would go about restructuring the Curia." (New York Times, N.11, 1976:5:6)

With the death of Jean Villot in March of 1979, John Paul named Archbishop Agostino Casaroli as secretary of 
state and Archbishop Giuseppe Caprio, papal undersecretary of state, as president of the powerful Administration of the Holy See Patrimony. Both positions had been held by villot before his death. (Providence Visitor, May3,1979,1:1)

The promotion of noted long-time diplomat, Casaroli, points to the Pope's preoccupation with international affairs and that he intends to follow through with Pope Paul's policies of detente. It is of significance that the two key posts in the Vatican administration have reverted to Italian control. Time magazine (May,4,1979:98) reports:

It was a foregone conclusion that a Polish Pope with no Vatican experience would have to choose an Italian to help him deal with the predominantly Italian Secretariat of state.

The article also suggests that in naming Casaroli to this post and promoting him to the College of Cardinals, John Paul II was returning the favor. Pope Paul had sent his Eoreign minister Casaroli to Poland in 1967 on a visit and shortly thereafter Karol Wojtyla was named to the College of Cardinals.

If Vatican observers or non-Italian prelates were hopeful that this non-Italian Pope would internationalize his top executives, the evidence is to the contrary. On June 30, 1979, John Paul will elevate fourteen bishops to the College of Cardinals and the list includes six Italians, two Poles, and one each from France, Ireland, Japan and Vietnam. The list is notable for its lack of South American, African or U.S. candidates. (Providence Visitor, May31,1979, 
John Paul II is proving himself to be a charismatic religious leader generating popular support by his personal appearance, fluency in languages and identification with oppressed peoples. But the Vatican is also a political institution and this native son from Poland, an outsider, has to deal with the powerfully entrenched political bureaucracy in the Roman Curia and his success may depend as much on his diplomatic relations with it as well as those with foreign governments.

The Roman Catholic Church is also an actor with a dual role as it approaches the lower levels of society as a religious institution with an emotional appeal to their state in life. But it is also a corporate state in its own right when it deals with the upper levels of society, the executives and world officials. Whichever pose the Church adopts, it is calculated with an eye to accruing the best possible advantage for the church.

\section{Conclusion}

In highlighting some of the characteristics of the Catholic Church as a global enterprise, this study has suggested it is similar operationally to other multinational corporations. I feel that such an examination of the secular operations of the Catholic Church has also shed light on the future policies of other global concerns. Future inquiry could reveal whether the Catholic Church will become more like secular multinational corporations 
and/or whether secular multinational corporations will become more like the Catholic Church.

As global corporations seek the type of legitimacy and justification afforded the Catholic Church, the latter is seeking the advantages assured by a future religious cartel. Invoking the ultimate authority, Pope John Paul II said recently, "It is God who provokes the desire for unity," (Providence Visitor, July 5,1979,2:1) in addressing visiting patriarchs from the Greek orthodox Church during a meeting on June 28. Healing the breach between the eastern and western branches of the church, coupled with the ongoing attempts at reunification with the Protestant churches, herald the beginning of the establishment of the Catholic church as the universal church for all. Such a religious conglomerate would be subject to few, if any, controls or regulations and little, if any, competition--a model for other global corporations to emulate. 


\section{SELECTED BIBLIOGRAPHY}

"A Triumphal Return." Time, 18 June 1979, pp. 27-35.

Ball, George W. Global Companies: The Political Economy of World Business, Englewood Cliffs, N.J.: PrenticeHa11, 1975 .

Barnet, Richard \& Muller, Ronald. Global Reach, New York: Simon \& Schuster, 1974.

Blau, Peter. Bureaucracy in Modern Society, New York: Random House, 1971 .

Boulding, Kenneth E. The Organizational Revolution, Chicago: Quadrangle Books, 1953.

Braungart, Richard A. and Margaret M. Multi-National Corporate Expansion and Nation-State Developments: A Global Perspective, A.S.A. Annual Meeting, San Francisco, Calif., 1978 .

Chirot, Daniel. Social Change in the Twentieth century, New York: Harcourt, Brace, Jovanovich, 1977.

"The Church of the Poor." Time, 7 May 1979, p. 8.8.

Cray, David. Control Structures in American Multinational Corporations: An Evolutionary Model, A.S.A. Annual Meeting, San Francisco, Calif., 1978.

Etzioni, Anitai. Complex Organizations, New York: Holt, Rinehart \& Winston, 1965.

Galtung, Johan. "A Structural Theory of Imperialism," Journal of Peace Research, 1971.

Gollin, James. Worldly Goods, New York: Random House, 1971.

"How the Vatican Manages its Money." Inst. Invest., March 1977, vol. 11, PP. 161-163.

"Inside the Pope's Bank." Newsweek, 25 September 1978, vol. 92, pp. 13, 80 .

"Inside the Vatican." Business Week, 17 July 1978, p. 48. 
Kahn, Herman. The Future of the Corporation, New York: Mason \& Lipscomb, 1974.

Levinson, Charles. Capital, Inflation and the Multinationals. New York: MacMillan \& Co., 1971.

LoBello, Nino. The Vatican Empire, New York: Trident Press, $196 \overline{8}$.

MacEoin, Gary. The Inner Elite, Kansas City: Sheed, Andrews \& McMeel, Inc., 1978.

"More Foreign Policy Than Crusade." Economist, 27 August 1977, vol. 264, pp. 20-22.

"Naked as a Lamb." Economist, 22 August 1970, vol. 236, p. 30 .

New York Times, 8, 18 January, 17 March, 2 April 1975;

5 January, 11, 14 November, 30 December, 1976;

2 December 1978 .

"Opening the Books." Newsweek, 17 April 1972.

Pallenberg, Corrado. The Vatican Finances, London: Peter Owen, Ltd., 1971.

"Pope at War With Enemy Within." Economist, 8 July 1972, vol. 244, Pp. 46-47.

Providence Visitor, 3, 31 May, 15 March 1979, 5 July 1979.

"Red Carpet." Economist, 8 March 1975, vol. 254, p. 58.

"Responsible Church Investment." America, 5 February 1972, vol. 126, P. 111 .

"Right Hand Man." Time, 14 May 1979, P. 98.

"Roman Catholic Church: Transnational Actor." International Organizations, Summer 1971, pp. 479-502.

Rosenstein, Rodan. Multinational Investment in the Framework of Latin American Integration, See Inter American Development Bank, pp. 33-88, 1974.

Scheer, Robert. America After Nixon: The Age of the Multi Nationals, New York: McGraw-Hill, 1974.

"Some Changes Are Easier Than Others." Economist, 26 September 1970, vol. 236, p. 36. 
"Spirit Moves in Sundry Places." Economist, 20 March 1971, vol. $238, \mathrm{p} .30+$.

Steiner, George. Multinational Corporate Planning, New York: MacMillan \& Co., 1966.

"Still Founded on the Rock." Economist, l November 1969 , vol. 233 , p. $26+$.

"The Story of the Vatican and Its Wealth." U.S. News, April 26, 1965, vol. 58, pp. 70-72.

Tugendhat, Christopher. The Multinationals, New York: Random House, 1972 .

Turner, Louis. Invisible Empires: Multinational Companies and the Modern World, New York: Harcourt, Brace, Jovanovich, 1970 .

"Vatican and Iłaly Cut the Umbilical?" Economist, 27 August 1977, vol. 264, pp. 19-20.

"The Vatican as a World Power." Atlas, May 1970, vol. 19, pp. 15-16.

"Vatican Politics: Structure and Function." World Politics, July 1974, sec. 26, pp. 542-559.

"The Vatican's Riches." Economist, 27 March 1965, vol. 214, pp. 1403-1405.

"Vatican's Riches." Economist, 20 February 1965, vol. 214, p. 762 .

"The Vatican Secret Real Estate Dealings." Atlas, March 1977, vol. 24, pp. 25-27.

Vernon, Raymond, "Multinationals and Accountability." New York Times, 18 November 1973, p. Fl2.

Wallerstein, Immanuel. The Modern World System, New York: Academic Press, 1976.

Wells, Alan. World system Theory and the Multinational Corporation, Mid-South Sociological Association, Annual Meeting, November 2-4, 1978.

"Will the Catholic Church Survive?" New Statesman, 6 January 1967, pp. 73-74. 